
United States. Published by Cambridge University Press for the Arizona Board of Regents on behalf of the University of Arizona

\title{
WALLY BROECKER-USING RADIOCARBON FOR PUZZLES OF THE GLACIAL AND DEGLACIAL ENVIRONMENT
}

\author{
Dorothy Peteet*(1) \\ NASA Goddard Space Flight Center, 2880 Broadway, New York, NY 10025, USA; and Columbia University, \\ Lamont Doherty Earth Observatory, Palisades, NY 10964, USA
}

ABSTRACT. Wally Broecker's puzzles required radiocarbon dating in order to solve them.

KEYWORDS: abrupt climate change, AMS dating, pollen, Last Glacial Maximum, Younger Dryas.

\section{INTRODUCTION}

Peerless in his cutting-edge climate science, Wally Broecker had a passion for solving climate puzzles which revealed a rare combination of gifts. Fundamental to his genius were his grasp and familiarity with the broad paleoclimatic literature of ocean, ice core, and terrestrial realms coupled with his ability to translate the mysteries he saw to his colleagues and everyman. Scientific expertise demands intense depth of inquiry, but this additional cross-disciplinary breadth is most essential to solving big picture problems. His towering intellect resulted in a profound influence on climate science and on people. I was extremely privileged to share in three out of the many puzzles that he so eagerly pursued.

\section{Last Glacial Maximum (LGM)}

Wally was intrigued by the discrepancy between the CLIMAP's (1981) marine reconstruction of subtropical sea surface temperature during the LGM $(23,000-18,000$ years ago) and glacial equilibrium lines (Figure 1). The marine reconstruction produced subtropical temperatures that were warmer than today (Figure 2), which was in stark contrast to the terrestrial large dip in glacial equilibrium lines at low as well as high latitudes.

Wally recognized that other terrestrial evidence was needed to solve the problem, and I first worked with him for pollen data collection throughout the subtropics along with climate modeling at NASA/GISS. The radiocarbon-dated LGM pollen data throughout the subtropics indicated at least a $4.5^{\circ} \mathrm{C}$ cooling, in agreement with the glacial data, and global climate modeling revealed that the model could not simultaneously reproduce warm sea surface temperatures concurrently with cold low latitude land surfaces at the LGM (Rind and Peteet 1985). This puzzle then led to Wally's encouragement of groundwater noble gas measurements at LDEO made by Peter Schlosser and Martin Stute, and they also found terrestrial cooling of $4-5^{\circ} \mathrm{C}$ at subtropical latitudes (Stute et al. 1995).

A cooler climate at the LGM implies a greater climate sensitivity, and remains an important puzzle today, as climate models put this sensitivity anywhere between $4^{\circ}$ and $9^{\circ} \mathrm{C}$. This climate sensitivity question continues to bedevil scientists of all disciplines, as marine data at low latitudes continues to be much warmer than those from terrestrial sites (Seltzer et al. 2021).

The LGM question led Wally to organize a field trip of 22 scientists to the Andes in 1989 to examine the Southern Hemisphere snowlines in more detail, entraining glacial geologists and

*Corresponding author. Email: peteet@1deo.columbia.edu 


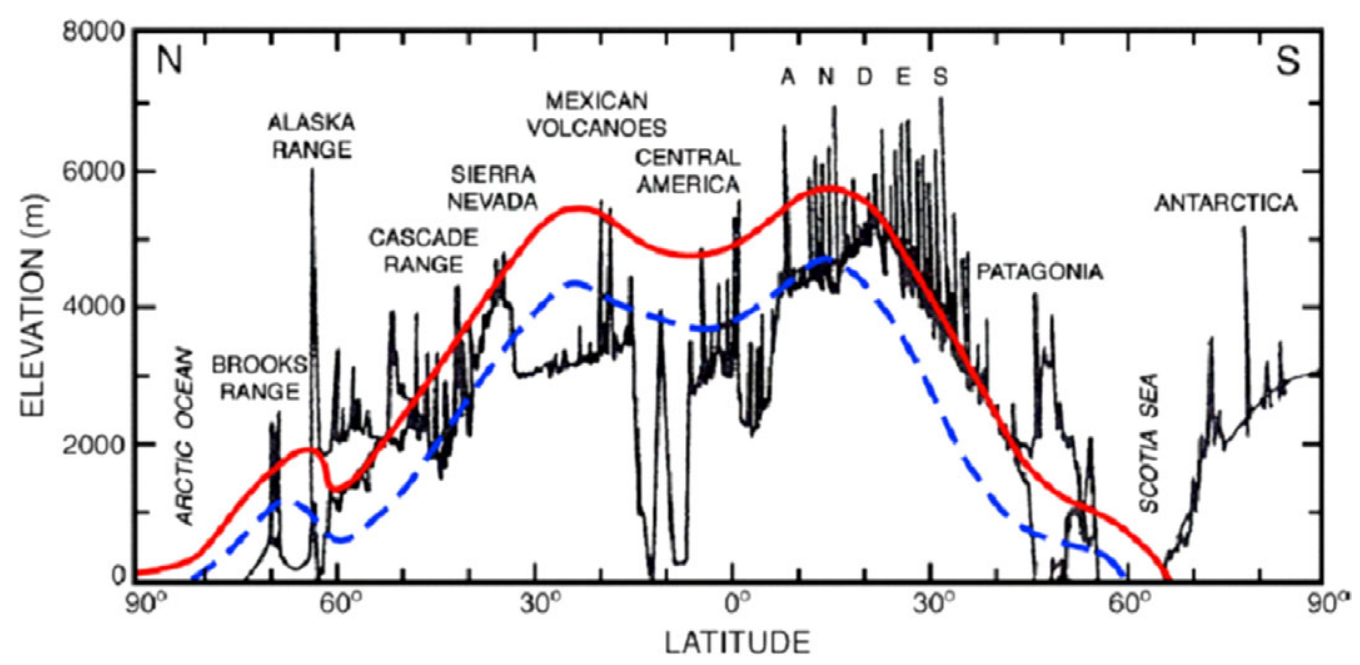

Figure 1 Adapted from S.C. Porter in Broecker and Denton (1989), showing LGM advance of snowlines almost $1 \mathrm{~km}$ both at low and high latitudes.

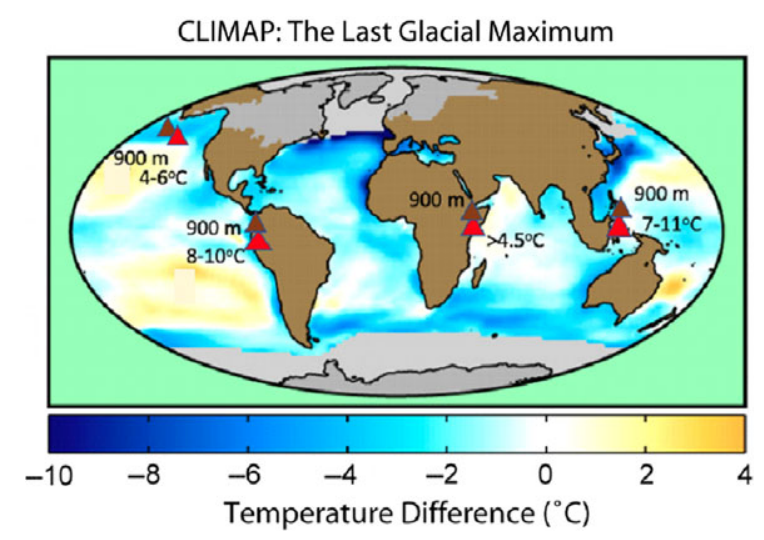

Figure 2 CLIMAP sea surface temperature change (LGMpresent) along with pollen (red) and snowline (maroon) data (adapted from Rind and Peteet 1985).

other paleoclimate colleagues from as far as Scotland, Bolivia, Chile, and Tasmania (Figure 3). $\mathrm{He}$ initiated collection of rock samples on that trip for subsequent ${ }^{10} \mathrm{Be}$ dating, encouraging new data collection globally.

\section{Abrupt Climate Shifts-The Younger Dryas}

With the extraction of the Greenland ice cores, whose efforts Wally strongly supported, and the discovery of abrupt shifts in climate and trace gases, Wally became fascinated by the causes of climate's rapid warmings and cooling, and the forcing for climate change. Comparison of European and North American terrestrial paleorecords with the marine North Atlantic and Greenland's ice cores led to clear patterns of the concurrent timing of warming along with ice retreat, and sudden returns to cold conditions. $\mathrm{AMS}-{ }^{14} \mathrm{C}$ dating of terrestrial 


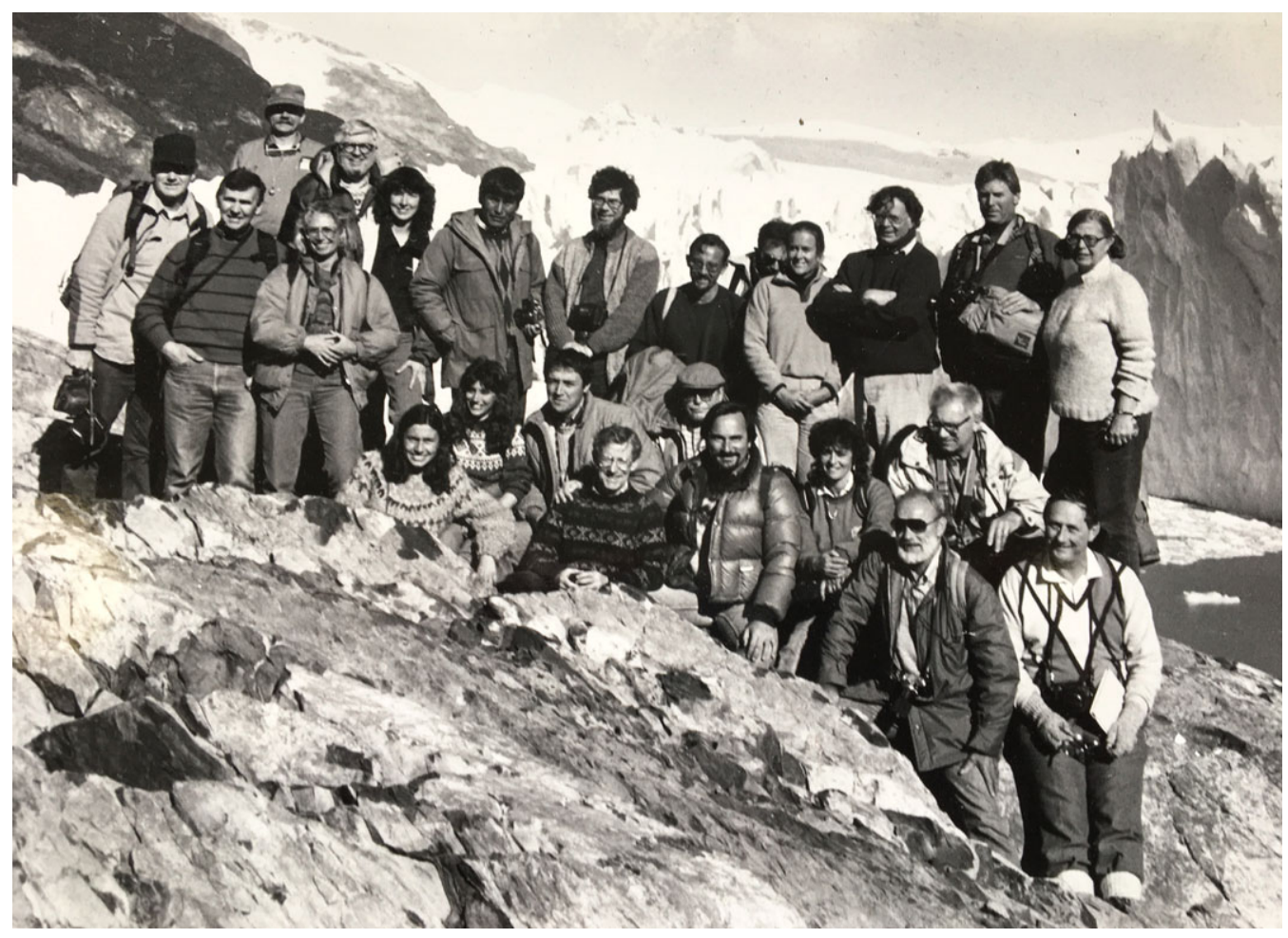

Figure 3 Photo of field trip participants at front of Moreno Glacier in Argentina. Wally Broecker is third from right, back row. (Participants are labeled from left to right.) Back row: George Denton, Ed Evenson, Calvin J. Heusser, Dorothy M. Peteet, Jaime Argollo, Chris Hendy, Marcello Zarate, unknown, Mary Stine, Wally Broecker, Scott Stine, Linda Heusser. 3rd row: Steve Porter, Lydia Espizua, Andrea Coronato, Martin Iriondo, Carlos Schubert. 2nd row: Cecilia Regairaz(?), Chalmers Clapperton, Jorge Rabassa, Monica Salemme, George Kukla. 1st row: Michel Hermelin, Eric Colhoun.

macrofossils such as leaves of Dryas octopetala (Figure 4) in the stratigraphic record became important linkages from site-site throughout Europe, and eventually in North America. Interglacial to Holocene terrestrial pollen stratigraphy from locations such as Grande Pile, France (Woillard 1978) indicating frequent climate oscillations was important in understanding the range and magnitude of these linkages.

The Younger Dryas was the most prominent of these coolings in the Northern Hemisphere, and as we plotted the pollen data (Figure 5) it was clear at that time that while the N. Atlantic saw a return of sea ice and Europe faced very cold conditions, in temperate $\mathrm{N}$. America conditions were not as severe. It was linkages of the Greenland ice core data to radiocarbon-dated sites in Europe along with N. Atlantic chemical data (Boyle and Keigwin 1982) that led Wally to his conclusion that changes in water transport might be important for climate change through the production rate of deep water and shifts in ocean circulation - the conveyor belt (Figure 6) hypothesis (Broecker et al. 1985).

\section{Timing of Deglaciation-Linkages of Land, Ocean, and Ice}

Wally's emphasis on improved AMS radiocarbon chronologies for linkages for land and ocean led him to pursue resident time questions for carbon in the ocean (Broecker et al. 1991) as well 


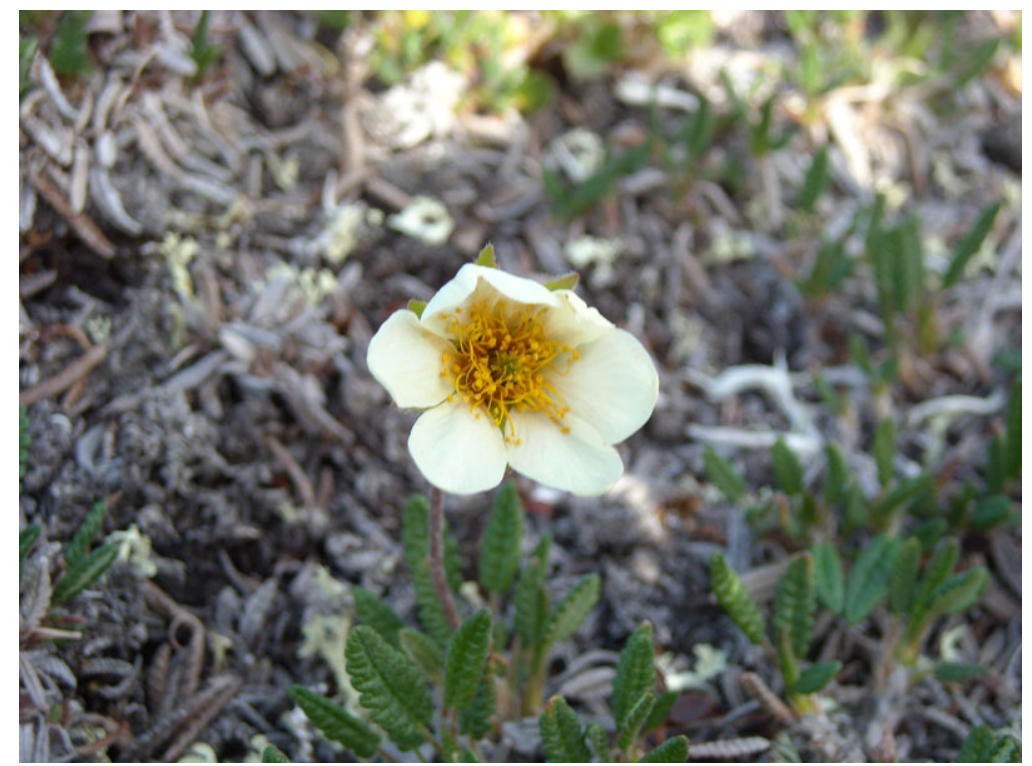

Figure 4 Dryas octopetala flower and leaves, an arctic/alpine member of the rose family for which the Younger Dryas was named.

24 REVIEWA

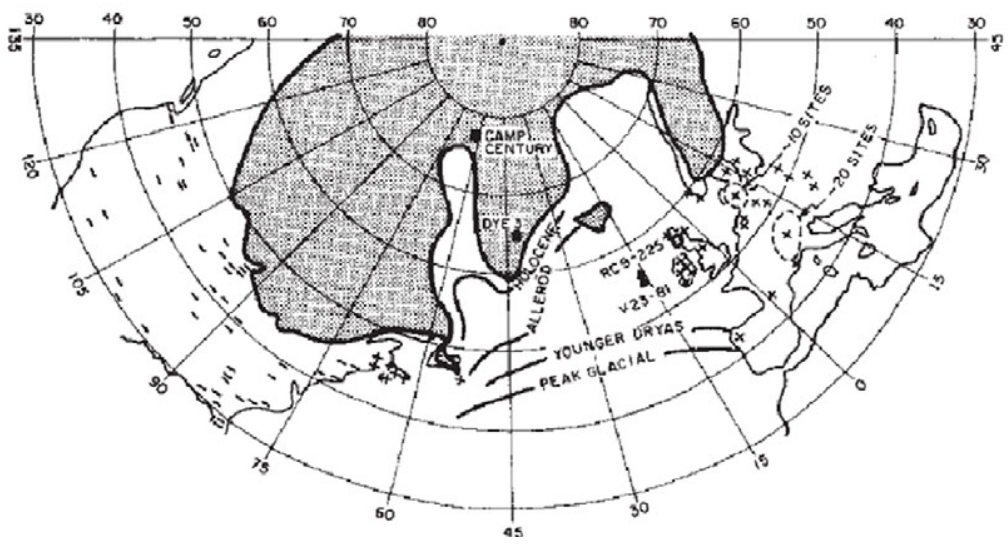

Figure 5 Pollen evidence $(+)$ for Younger Dryas cooling or lack of it $(-)$ in the Northern Hemisphere (Broecker et al. 1985).

as the comparison of the timing of warming in northern and southern hemispheres, and wet and dry intervals around the globe (i.e., Broecker et al. 1998). His conclusion that shifts of the thermal equator were linked to sea ice cover at the poles and ocean circulation reorganization were confirmed by the faraway chronologies such as Santa Barbara basin (Kennett and Ingram 1995), Cariaco Trench (Hughen et al. 2000), and Lake Titicaca (Baker et al. 2001). Abrupt climate changes occurred throughout the globe, as evidenced by the crucial radiocarbon chronology. 


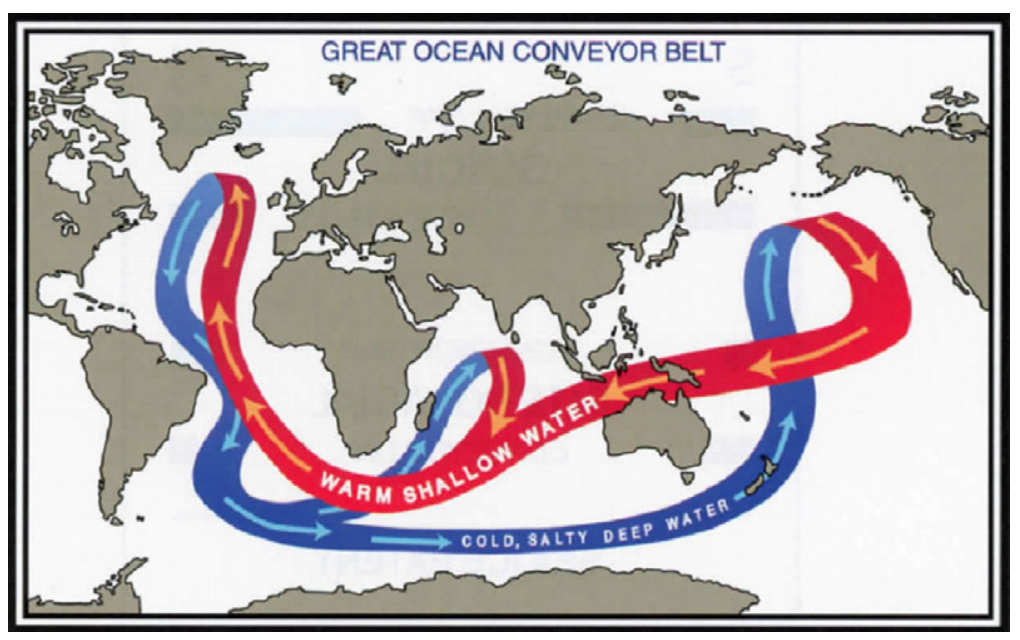

Figure 6 Cartoon depicting conveyor belt showing global loop in thermohaline circulation which Wally suggested was a factor in rapid climate change (Broecker et al. 1985; Broecker 1987).

Wally's intellect, curiosity, and humanity shone through all of his interactions, as well as his prodigious energy. His transformative and outsize influence partly hinged on his translation of the complicated climatic signals and mechanisms to simple language as master storyteller. The remarkable Oak Park, Illinois high school English Department that he learned from had similarly nurtured Ernest Hemingway decades earlier. His generosity was remarkable, as he always had an open door for anyone. He inspired technicians, assistants, and students throughout many decades, proved loyal to his colleagues and friends, and cared not for things, but people and ideas. He was a lot of fun to be around and argue with. We miss him profoundly.

\section{REFERENCES}

Baker P, Seltzer G, Fritz S, Dunbar R, Grove M, Tapia P, Cross S, Rowe H, Broda J. 2001. The history of South American tropical precipitation for the past 25,000 years. Science 291:640-643.

Boyle E, Keigwin L. 1982. Glacial to interglacial change in the cadmium content of deep Atlantic water. Science 218:784-787.

Broeker W. 1987. The biggest chill. Natural History Magazine 97(10):74-82.

Broecker W, Peteet D, Rind D. 1985. Does the oceanatmosphere system have more than one stable mode of operation? Nature 315:21-26.

Broecker WS, Denton GH. 1989. The role of oceanatmosphere reorganizations in glacial cycles. Geochimica et Cosmochimica Acta 53:2465-2501.

Broecker WS, Klas M, Clark E, Bonani G, Wolfli W. 1991. Chemical erosion in the equatorial Pacific. Paleoceanography 6:593-608.

Broecker WS, Peteet D, Hajdas I, Lin J, Clark E. 1998. Antiphasing between rainfall in Africa's rift valley and north America's great basin. Quaternary Research 50(1):12-20.

CLIMAP Project Members. 1981. Seasonal reconstructions of the Earth's surface at the last glacial maximum. Geological Society of America Map and Chart Series MC-36:18.

Hughen K, Southen JR, Lehman SJ, Overpeck JT. 2000. Synchronous radiocarbon and climate shifts during the last Deglaciation. Science 290:1951-1954.

Kennett JP, Ingram BL. 1995. A 20,000-year record of ocean circulation and climate change from the Santa Barbara basin. Nature 377:510-514.

Rind D, Peteet DM. 1985. Terrestrial conditions at the last glacial maximum and CLIMAP sea surface temperature estimates: Are they consistent? Quaternary Research 24:1-22.

Seltzer A, Ng J, Aeschbach W, Kipfer R, Kulongoski J, Severinghaus J, Stute M. 2021. Widespread $6^{\circ} \mathrm{C}$ 
cooling on land during the last glacial maximum. Nature 593:228-235.

Stute M, Clark JF, Schlosser P, Broecker WS, Bonani G. 1995. A 30,000 yr continental paleotemperature record derived from noble-gases dissolved in groundwater from the San-Juan Basin, NewMexico. Quaternary Research 43(2):209-220.

Woillard G. 1978. Grande Pile Peat Bog: a continuous pollen record for the past 140,000 years. Quaternary Research 9:1-21. 